\title{
Determinants of Companies' Board Composition in Emerging Markets
}

\author{
Leticia L. N. Bellato $^{1,2}$ \\ ${ }^{1}$ Fundação Getúlio Vargas - EAESP, São Paulo, Brazil \\ ${ }^{2}$ Banco Central do Brasil, São Paulo, Brazil \\ Correspondence: Leticia L. N. Bellato, Fundação Getúlio Vargas - EAESP, Sao Paulo, Brazil.
}

Received: February 16, 2021

Accepted: March 25, 2021

Online Published: September 2, 2021

doi:10.5430/ijba.v12n5p17

URL: https://doi.org/10.5430/ijba.v12n5p17

\begin{abstract}
This paper examines the determinants of female board representation for a sample of Brazilian listed companies for the year of 2018. Using count data models, we find that greater firm size, performance and board size lead to higher woman representation on companies' boards. Also, that private control is associated with a lower number of women on boards. Most studies related to board composition focus on independent directors and are conducted in a developed countries' setting. This work contributes to the extant literature in understanding what drives woman representation on corporate boards in an emerging market context and also would help to support the definition and implementation of gender diversity policies by showing possible impacts.
\end{abstract}

Keywords: corporate governance, corporate boards, board composition, women, gender diversity, emerging markets

\section{Introduction}

Boards play a fundamentally important role in the corporate governance of companies, and therefore understanding the determinants of board composition is a relevant research question (Guest, 2008).

Although it is documented that entities benefit from having women representation on corporate boards (Adams \& Ferreira, 2009), women are still underrepresented among companies, especially in developing countries (Spencer Stuart, 2018; Terjesen, Aguilera \& Lorenz, 2015).

Previous studies of gender diversity on the board have focused on the consequences of having women on boards (Adams \& Ferreira, 2009; Chong, Ong \& Tan, 2018). Research considering what drives companies to appoint women on their boards is scarce (Hillman, Shropshire \& Cannella, 2007; Ahmed, Higgs \& Delaney, 2018). Besides that, these studies were conducted in developed countries.

As Linck, Netter \& Yang (2008) find pronounced differences in the determinants of board structure between small and large firms and Guest (2008) also shows evidence that board structure determinants differ across different institutional settings comparing UK to US studies, it can be possible that the results for board gender composition would be different in emerging markets from the extant literature.

The objective of the research is to understand the determinants of the aspects of companies' corporate governance (board composition). This study will have a greater focus on the diversity of the composition of the board as the extent of the presence of members that are woman.

This study offers contribution to two strands of extant literature. First, this paper relates to the literature that investigates what factors shape board composition (Boone et al., 2007; Chen \& Al-Najjar, 2012, Coles, Daniel \& Naveen, 2008; Guest, 2008; Linck et al., 2008) and, more specifically, board gender composition (Hillman et al., 2007). Our empirical analysis complements these works as it focus on gender representation in corporate boards and in an emerging market setting and also tests the same (Hillman et al., 2007) and new methodology with count data models. Second, this work relates the literature that studies regulation on board gender composition (Bøhren \& Staubo, 2014; Sojo, Wood, Wood \& Wheeler, 2016), as it results show possible impacts of actions by governments and organizations that aims to raise the proportion of women in senior leadership roles. 


\subsection{Board Gender Diversity}

Although gender diversity of the board is a central theme of reform efforts to improve corporate governance around the world (Adams \& Ferreira, 2009), women have failed to achieve equal representation on corporate boards as females represent only $10.3 \%$ of corporate boards across 67 countries (Terjesen et al., 2015).

The studies that examine the effect of board gender composition on firm performance have mixed results (Kirsch, 2018) and some of them also show different impact depending on the analyzed firms (Adams \& Ferreira, 2009). Overall, studies have shown a negligible effect of boards' gender composition on firm financial performance and a positive effect on social and ethical aspects of companies' behavior and on gender diversity below board level (Kirsch, 2018). In addition, a growing number of works assert that it provides benefits to firms' corporate governance (Ye, Deng, Liu, Szewczyk \& Chen, 2019), as greater female representation would improve the board's monitoring role in protecting shareholder interests (Adams \& Ferreira, 2009; Mateos de Cabo, Gimeno \& Nieto, 2012).

However, a recent growing literature questions the view that female directors behave differently than their male counterparts and show that woman behave in the same way in corporate high-level positions (Lara, Osma, Mora \& Scapin, 2017, Mateos de Cabo, Gimeno \& Escot, 2011).

From policies' point of view, it is unclear how a successful regulation outcome should be defined. Outcomes can be expected regarding firm behavior, firm performance and/or outcomes for women (Kirsch, 2018).

Besides that, Bøhren, Ø. \& Staubo (2014) find that, in Norway, when new legislation required in 2003 at least $40 \%$ of men and women in boardrooms, half of the companies choose to change to an organizational form not exposed by the law and that the tendency to avoid the regulation varied systematically with firm characteristics, showing existing costs for restructuring the board and that this cost changed by firm.

\subsection{Determinants of Board Composition}

Despite the importance of boards of directors and the widespread call for their reform, literature have reached few definitive conclusions about the forces that drive board composition (Boone et al., 2007) and few studies focus specifically on women representation on boards.

The research literature in this area has developed several theoretical hypotheses concerning determinants of board structure and composition, mainly in the developed countries (Chen \& Al-Najjar, 2012).

Boone, Field, Karpoff \& Raheja (2007) tests three hypotheses for the determinants of board structure and composition, more specifically related to number of directors and proportion of independent members, respectively. The first hypothesis, which reflects the views of Fama \& Jensen (1983), implies that board structure is driven by the scope and complexity of the firm's operations (scope of operations hypothesis). The second hypothesis is that board size and composition are determined by the specific business and information environment in which the firm operates (monitoring hypothesis), and the third hypothesis implies that board composition results from a negotiation between the firm's CEO and its outside board members (negotiation hypothesis).

The determinants of board size studied include organization size, organization age, growth opportunities, growth, diversification and firm complexity (Ali, 2018; Boone et al., 2007; Coles et al., 2008; Linck et al., 2008).

Researchers have investigated some individual and firm influences on women's promotion to board directorships, identifying resource dependency, network ties, and organizational and industry characteristics (Hillman et al. 2007). Existing literature also examines institutional factors impacting the pre-quota legislation percentages of women on boards, including the proportion of female senior managers, gender pay gap, history of female political representation, and national economic and cultural environments (Terjesen et al., 2015).

Adopting the resource dependence theory, Hillman et al. (2007) identified organizational characteristics that influence women's representation on corporate boards: firm size, industry type, firm diversification and board networks.

Other studies find that women directors are more prevalent in firms with large boards, in established firms, in either large firms or small family firms, and in firms with foreign institutional investors (Kirsch, 2018). Other papers also consider sectoral variation and find, e.g., fewer women in the STEM (Science, technology, engineering, and mathematics) and finance industries (Adams \& Kirchmaier, 2016).

This research will be based on the agency theory and resource dependency theory. Agency theory is concerned with aligning the interests of owners and managers (Jensen \& Meckling, 1976) and is based on the premise that there is an 
inherent conflict between the interests of a firm's owners (principal) and its management (agents). The Board of Directors is appointed by the shareholders to monitor and control managerial decision making to protect the shareholders' interests. According to agency theory, firm owners would appoint woman to boards to enhance the monitoring capabilities of the board, as they are more likely than man to closely monitor managers (Kirsch, 2018). The resource-based theory emphasizes the importance of the quality of the unique resources of the company and the firm's relationships with the business environment.

Young, Peng, Ahlstrom, Bruton \& Jiang (2008) highlight that instead of traditional principal-agent conflicts (PA conflicts) adopted in most research in developed countries, principal-principal conflicts (PP conflicts) have been identified as the main concern of corporate governance in emerging markets. PP conflicts between controlling shareholders and minority shareholders result from concentrated ownership, extensive family ownership and control, business group structures, and weak legal protection of minority shareholders. Besides that, they emphasize that such PP conflicts alter the dynamics of the corporate governance process and, in turn, require different treatments from those related to PA conflicts. Thus, as the board is one of the main topics in corporate governance, it should be possible that the drivers in developing countries would be different from developed countries.

The purpose of the research is to analyze if and in which extent companies' board composition is determined by firm characteristics in emerging markets. The hypotheses will be tested in the Brazilian context, as Brazil presents one of the lowest percentages of woman on the board in the international comparison of Spencer Stuart (2018) and, until the moment, differently from some developed countries (Norway, Spain, France, Italy, Netherlands), did not implement any kind of compulsory rules. In addition, Brazil has one of the largest economies in the world and the country's institutional setting and corporate governance of companies represent well the profile of emerging markets.

\subsection{Regulation on Boards' Women Representation in Brazil}

Sojo et al. (2016) identify two kinds of strategy to increase woman representation on boards. The first type is from the supply-side, which are strategies to supplement equal opportunity efforts, as mentoring, targeted development, and networking. However, the failure of supply-side strategies to generate acceptable growth in women representation in senior leadership roles has led some countries to adopt demand-side strategies: reporting requirements on gender breakdown of leadership positions, targets set goals for women occupation or nomination for senior leadership roles with minimal or no enforcement mechanisms or sanctions and finally government or industry mandated representation of each gender in leadership positions along with enforcement mechanisms (quotas).

To address the gender diversity issue on corporate boards, Brazil only adopts recommended practices on diversity, including gender, by Brazilian Institute of Corporate Governance (IBGC) Code of Best Practices. Moreover, Brazil has an attempt to implement quota regime for public companies, which aims to oblige this companies to have at least $30 \%$ of women in their non-executive boards. The law was first proposed in 2010 as PLS 112/2010. The Law Proposal was approved by the Senate in 2017, becoming PL 7179/2017 (Abreu, 2019). Recently, this proposal became PL 785/2021 in the Chamber of Deputies and is under current analyses.

Besides that, as supply side initiative, Brazil has applied a mentoring initiative sponsored by the Brazilian Stock Exchange (B3), Brazilian Institute of Corporate Governance (IBGC), International Finance Corporation (IFC), Spencer Stuart e Women Corporate Directors Foundation (WCD) since 2014. By the demand-side, the Brazilian Securities and Exchange Commission (CVM), by Instruction CVM 586/2017, required for Brazilian listed companies to disclose information about the compliance or not to the "Brazilian Code of Corporate Governance Public Companies", which generically states that gender diversity should be considered in the board?

\section{Data and Measures}

\subsection{Sample}

The data was compiled from several sources. Data from board structure and composition was obtained from 2018 Spencer Stuart Board Index report (Spencer Stuart, 2018) and financial data from Economatica database. In the Spencer Stuart Index report for Brazil, it was available data for the boards of 187 companies for 2018, but 6 companies were eliminated because they had no longer shares listed at B3 by the end of 2018 and accounting data were not available at Economatica.

The final sample consisted of 181 companies listed at least in one of the three differentiated corporate governance segments of the Brazilian Stock Exchange B3 (Level 1, Level 2 or New Market), with observations for 2018. The sample of firms was limited by the availability of data by Spencer Stuart Report (only companies listed in one of the three differentiated corporate governance segments of the Brazilian Stock Exchange). 
Data goes back to 2017 because we also run one of the models using lagged values of Tobin's Q as instrument for current values. The Spencer Stuart Index report for Brazil started in 2016 but data on board structure and composition of the reports for the years of 2016 and 2017 were not used because of the important 2015-2016 Brazilian crisis scenario that represented an accumulated drop in the GDP by more than $8 \%$.

\subsection{Measures}

\subsubsection{Dependent Variables}

In this research we used two variables to study the participation of woman on corporate boards:

Female board representation: the dependent variable of interest was coded 1 if a firm's board of directors included at least one woman and 0 otherwise (Hillman et al., 2007).

Female board members: number of women on the board (Chong et al., 2018).

\subsubsection{Regressors}

The independent variables that were used are:

Average board age: average board age (Chen, Leung \& Goergen, 2017) calculated by Spencer Stuart.

Board Size: number of board members of each organization (Ali et al., 2018; Guest, 2008).

Corporate governance: two dummies for Level 2 and New Market differentiated corporate governance levels of the Brazilian Stock Exchange B3 of the three levels (Level 1, Level 2, or New Market).

Firm Size: measured as companies' total assets and by net revenues (Chen and Al-Najjar, 2012).

Firm Industry: classification on the two-digit NAICS level and one-digit NAICS level.

Firm control: companies classified as having private, public, or foreign control and we use dummies for public and foreign control.

Free cash flow (FCF): cash holdings divided by total assets (Boone et al., 2007; Guest, 2008; Linck et al. 2008).

Leverage: defined as the ratio of total debt (short and long-term debt) to total assets (Chen \& Al-Najjar, 2012; Chen et al., 2017).

Performance: return on assets - ROA (Adams \& Ferreira, 2009; Boone et al., 2008; Guest, 2008) and Tobins' Q proxied as enterprise value divided by total assets (Adams \& Ferreira, 2009; Chen \& Al-Najjar, 2012).

Tenure: board members' tenure in a maximum of two years according to the requirements of the differentiated corporate governance levels of the Brazilian Stock Exchange B3.

\section{Econometric Analysis}

In this research we conduct several alternative analyses. First, we run a logistic regression with odds ratio, as it is easier to interpret the results, and compare it with the findings of Hillman et al. (2007) for differences in companies that have from those that do not have female on boards.

Finally, we used count data models with the dependent variable of the number of women directors as Negative Binomial and Poisson models, since we have in the sample concentrated few small discrete values.

\subsection{Endogeneity Issues}

Potential measurement error in the proxy variables can lead to attenuation bias where reported results are understated, and we therefore follow Boone et al. (2007), Guest (2008) and Linck et al. (2008) and use multiple proxies for the variables when possible. Also, endogeneity problems can occur if board composition and firm specific measures are jointly determined by unobservable factors or if board composition impacts firm specific measures rather than vice versa. In order to reduce endogeneity problems, we used industry dummy variables to control for industry effects (Guest, 2008).

Another endogeneity problem is that of reverse causality, whereby firm specific explanatory variables are determined by board composition rather than vice versa. In order to address this, we will follow Guest (2008) and re-estimate in an instrumental variables' framework, using lagged values of Tobin's $Q$ as instrument for current values.

\section{Descriptive Statistics}

In our data almost $54 \%$ of the boards has no woman as a director and $46 \%$ of firms have at least one female director in 2008 . Only $22 \%$ of the companies have two or more female directors and $9 \%$ have three or more women on the board. The maximum number of female directors was six in only one of the companies. 
Table 1 provides means, standard deviations, and correlations for the independent variables:

Table 1. Descriptive statistics and correlation matrix

\begin{tabular}{lllllllllll}
\hline & Mean & S.D. & 1 & 2 & 3 & 4 & 5 & 6 & 7 & 8 \\
\hline 1. Assets & $45,407,808$ & $201,678,052$ & & & & & & & & \\
\hline 2. ROA & 8.9 & 109.2 & -0.01 & 1.00 & & & & & & \\
\hline 3. Debt Ratio & 72.8 & 68.4 & -0.03 & 0.36 & 1.00 & & & & & \\
\hline 4. Tobin's Q & 1.0 & 0.8 & -0.08 & 0.24 & 0.07 & 1.00 & & & & \\
\hline 5. Members & 8.9 & 4.0 & 0.13 & -0.05 & -0.15 & 0.03 & 1.00 & & & \\
\hline 6. Average Age & 55.6 & 7.0 & 0.05 & -0.21 & -0.05 & 0.06 & -0.12 & 1.00 & & \\
\hline 7. FCF & 0.02 & 0.14 & 0.05 & -0.66 & -0.36 & -0.10 & 0.06 & 0.12 & 1.00 & \\
\hline 8. Tenure & 1.7 & 0.5 & 0.08 & -0.12 & -0.19 & -0.04 & 0.13 & 0.01 & 0.07 & 1.00 \\
\hline
\end{tabular}

There are not particularly high bi-variate correlations among the independent variables (the highest being -0.6639) and for this reason our model is not affected by the multicollinearity problems.

We also tested for multicollinearity conducting OLS regressions to generate variance inflation factors (VIF) and found that the maximum VIF was 2.08 (Appendix C), a value well below the accepted maximum of 10 (Hillman et al., 2007).

\section{Results}

Table 2 provides the results of the logistic regression analysis for a model using ROA as a proxy for performance and another model using Tobins' $\mathrm{Q}$. The results of the models are very similar independent of the variable of performance. We report odds ratios rather than coefficients. Odds ratios represent the change in the likelihood of a dependent variable arising from a one-unit change in the independent variable. The odds ratios greater than 1.00 indicate that increases in the independent variable increase the likelihood of the dependent variable (having one or more women on the board). Odds ratios of less than 1.00 indicate that increases in the independent variable are associated with decreases in the likelihood of having women on the board.

Table 2. Logistic regression analysis for the presence of women directors ${ }^{\mathrm{a}}$

\begin{tabular}{|c|c|c|c|c|}
\hline Variables & Odds Ratio (Q) & S.E. & Odds Ratio (ROA) & S.E. \\
\hline Firm Size & $1 * *$ & 0.0000 & $1 * *$ & 0.0000 \\
\hline Performance & 1.7745 & 0.9047 & 0.9827 & 0.0120 \\
\hline Board Size & $1.8028 * * *$ & 0.2605 & $1.8058^{* * *}$ & 0.2409 \\
\hline Average Board Age & 0.9969 & 0.0385 & 1.0114 & 0.0385 \\
\hline Tenure & $0.2386 * *$ & 0.1442 & $0.2827 * *$ & 0.1719 \\
\hline Leverage & 1.0030 & 0.0048 & 1.0013 & 0.0054 \\
\hline Free-cash-flow (FCF) & $490.7285 * * *$ & $1,096.2310$ & $566.7025 * * *$ & $1,242.3050$ \\
\hline Dummy Firm Industry & \multicolumn{2}{|l|}{ Yes } & \multicolumn{2}{|l|}{ Yes } \\
\hline Dummy CG & \multicolumn{2}{|l|}{ Yes } & \multicolumn{2}{|l|}{ Yes } \\
\hline Dummy Firm Control & \multicolumn{2}{|l|}{ Yes } & \multicolumn{2}{|l|}{ Yes } \\
\hline Log pseudolikelihood & \multicolumn{2}{|l|}{-64.8489} & \multicolumn{2}{|l|}{-65.4867} \\
\hline Pseudo R2 & \multicolumn{2}{|l|}{0.3634} & \multicolumn{2}{|l|}{0.3571} \\
\hline$n$ & \multicolumn{2}{|l|}{147} & \multicolumn{2}{|l|}{147} \\
\hline${ }^{\mathrm{a}}$ Odds ratios are report & & & & \\
\hline
\end{tabular}


The results of the logistic regressions are not similar to that of Hillman et al. (2007) that found that organizational size is positively associated with female board representation. We highlight that we used a different proxy for firm size as the total assets differently from Hillman et al. (2007) that used the logarithm of sales. The results do not support the hypothesis, based on resource-based theory, that larger organizations are expected to face greater liabilities regarding legitimacy and to respond to societal pressures for greater gender diversity in their corporate boardrooms. The evidence in Table 2 do not support this hypothesis. The odds ratio for the firm size indicates that moving from the sample mean to one unit above the mean in firm size does not change the likelihood of female representation on a board of directors (odds ratio 1 and p-value<0.05).

As in Hillman et al. (2007) research, the board size was significantly associated with female board representation, indicating that an increase in one member in the board increases in $80 \%$ the likelihood of having at least one female director on the board (odds ratio of 1.80 and $\mathrm{p}$-value $<0.01$ ).

The free cash flow (FCF) variable is used as a proxy for incentives for controlling shareholders to extract private benefits of control, following Boone et al. (2008). The results provide support for the monitoring hypothesis, differently from the results of Boone et al. (2008) for independent directors in the US market, that predicts that the possibility of women representation on boards is higher when there is higher possibility of controlling shareholders to extract private benefits. In the PP conflict context of corporate governance in emerging markets, we can interpret this as controlling shareholders upholding women on boards as they can help monitoring the firm.

The results also indicate that an increase in board members' tenure is associated with a decrease in the probability to have a feminine director in the board.

We also conducted Poisson and Negative Binomial regressions using the number of women directors on the board as the dependent variable (Table 3). The models presented in Table 3 are: Poisson with no control for firm industry (Model 1), Poisson with control for firm industry (Model 2), Poisson with robust standard errors with control for firm industry (Model 3), Negative Binomial Model with firm industry control (Model 4), Negative Binomial Model with robust standard errors with no firm industry control (Model 5), Negative Binomial Model with robust standard errors with firm industry control (Model 6) and Negative Binomial Model with robust standard errors with firm industry control using classification on the one-digit NAICS level instead of two-digit NAICS level (Model 7). The model 1 is preferred as it presents the lower AIC and BIC and also, in the LR test, the p-value of 0.567 indicates that the extra variables do not substantially improve model fit (Model 1 preferred to Model 2). We also conducted a test of overdispersion presented by Cameron and Trivedi (2009, p. 561) and the outcome indicates that the overdispersion is not significant ( $\mathrm{p}$-value of 0.21), suggesting that a NB model or a Poisson with robust standard errors are not necessary.

The likelihood ratio test at the bottom of the negative binomial models provided by the software Stata is a test of the overdispersion of alpha parameter. When the overdispersion parameter is zero, the negative binomial distribution is equivalent to a Poisson distribution. In this case, alpha is not significantly different from zero and thus reinforces that the Poisson distribution is appropriate.

Table 3. Female board representation: Poisson and negative binomial models

\begin{tabular}{llllllll}
\hline Variables & Poisson & Poisson & $\begin{array}{l}\text { Poisson } \\
\text { vce }\end{array}$ & NB & NB vce & NB vce & NB vce 1 \\
\hline Firm Size & $0.0000^{*}$ & 0.0000 & 0.0000 & 0.0000 & $0.0000^{* *}$ & 0.0000 & 0.0000 \\
& $(0.0000)$ & $(0.0000)$ & $(0.0000)$ & $(0.0000)$ & $(0.0000)$ & $(0.0000)$ & $(0.0000)$ \\
\hline Performance & $0.2312^{* *}$ & $0.2749^{* *}$ & $0.2749^{* *}$ & $0.2749^{* *}$ & $0.2411^{* *}$ & $0.2749^{*}$ & $0.3205^{* * *}$ \\
& $(0.0972)$ & $(0.1383)$ & $(0.1535)$ & $(0.1383)$ & $(0.1178)$ & $(0.1535)$ & $(0.1179)$ \\
\hline Board Size & $0.1335^{* * *}$ & $0.1502^{* * *}$ & $0.1502^{* * *}$ & $0.1502^{* * *}$ & $0.1434^{* * *}$ & $0.1502^{* * *}$ & $0.1330^{* * *}$ \\
& $(0.0138)$ & $(0.0249)$ & $(0.0231)$ & $(0.0249)$ & $(0.0218)$ & $(0.0231)$ & $(0.0226)$ \\
\hline Average Board Age & -0.0038 & -0.0071 & -0.0071 & -0.0071 & -0.0009 & -0.0071 & -0.0067 \\
& $(0.0127)$ & $(0.0175)$ & $(0.0178)$ & $(0.0175)$ & $(0.0134)$ & $(0.0158)$ & $(0.0147)$ \\
\hline Tenure & -0.2315 & -0.3829 & -0.3829 & -0.3829 & -0.3129 & -0.3829 & -0.3598 \\
\hline
\end{tabular}




\begin{tabular}{llllllll}
\hline & $(0.1814)$ & $(0.2473)$ & $(0.2953)$ & $(0.2472)$ & $(0.2553)$ & $(0.2953)$ & $(0.3089)$ \\
\hline Leverage & 0.0009 & 0.0014 & 0.0014 & 0.0014 & 0.0010 & 0.0014 & 0.0010 \\
& $(0.0015)$ & $(0.0019)$ & $(0.0017)$ & $(0.0019)$ & $(0.0011)$ & $(0.0017)$ & $(0.0015)$ \\
\hline Free-cash-flow (FCF) & 0.7609 & 1.2071 & 1.2071 & 1.2071 & 0.9314 & 1.2071 & $1.2527^{*}$ \\
& $(0.7897)$ & $(0.9773)$ & $(0.7372)$ & $(0.9773)$ & $(0.6791)$ & $(0.7372)$ & $(0.7516)$ \\
\hline Dummy Firm Industry & No & Yes & Yes & Yes & No & Yes & Yes \\
\hline Dummy Firm Control & No & Yes & Yes & Yes & No & Yes & Yes \\
\hline Dummy CG & No & No & No & No & No & No & No \\
\hline Log pseudolikelihood & -190.38 & -167.53 & -167.53 & -167.53 & -189.59 & -167.53 & -180.00 \\
\hline Pseudo R2 & 0.1955 & 0.2921 & 0.2921 & 0.2471 & 0.1480 & 0.2471 & 0.1911 \\
\hline AIC & 396.764 & 447.056 & 445.056 & 447.056 & 397.181 & 443.0559 & 413.9904 \\
\hline BIC & 421.897 & 622.989 & 617.847 & 622.989 & 425.456 & 612.7057 & 498.8154 \\
\hline $\mathrm{n}$ & 171 & 171 & 171 & 171 & 171 & 171 & 171 \\
\hline
\end{tabular}

Note: Standard errors in parentheses, $* \mathrm{P}<0.10 ; * * \mathrm{P}<0.05 ; * * * \mathrm{P}<0.01$

Female board representation is determined by firm-specific characteristics and governance variables as revealed by in the model without controlling for firm industry: firm size, performance and board size (Table 3). However, once firm industry is controlled for, the effect of firm size variable is overshadowed by firm industry and become non-significant. When introducing dummies for firm industry and firm control, we observe many dummy variables of firm industry that are significant and also the dummy of private control has a negative relation with female board representation comparing with the base category (public control) and is significant at $10 \%$. This result is different from that found by Chen \& Al-Najjar (2012) in China in relation to independent directors that the state ownership has a robust negative impact on board independence.

The coefficients of the Poisson models can be interpreted as semi-elasticities. The 0.1335 coefficient of the Board Size variable is interpreted as one more member in the board is associated with increase of $13.35 \%$ in the number of women on the boards. Thus, an increase in firm size, performance and board size is associated with an increase in female board representation.

To address reverse causality, we re-estimate Model 1 in an instrumental variable framework, using lagged values of Tobin's Q (Tobins' Q for 2017) as instrument for current values (Guest, 2008). We applied a two-step procedure to the Poisson Model (Cameron and Trivedi, 2009, p. 593), considering Tobins' Q as endogenous. The first step generates residuals from a linear probability regression of Tobins' $\mathrm{Q}$ on regressors and instrument. The instrument is highly statistically significant with expected positive coefficient sign. The second step fits a Poisson model on regressors that include the first step residual. The $\mathrm{z}$ statistic of the coefficient lupaht provides the basis for a robust Wald test of the null hypothesis of exogeneity and one-sided test may be appropriate because it was proposed in a priori grounds. The $\mathrm{z}$ statistic has a $\mathrm{p}$-value of 0.199 , and in a one-side test a p-value of 0.099 , leading to nonrejection of the null hypothesis at a 0.05 level. Thus, we conclude for the exogeneity of Tobins' $Q$, supporting the study results.

\section{Concluding Remarks}

Despite recent advances, theoretical papers about determinants of board composition have mostly investigated independent directors' representation and empirical studies have focused mainly on US firms. We consequently have little knowledge of how determinants of board structure differ in countries with different legal, institutional, and regulatory systems. However, board functions and their effectiveness may differ according to these characteristics, and so consequently may the determinants of board composition. Examination of other countries is therefore useful in developing a broader view of what determines board composition (Guest, 2008).

In this research we tried to understand the determinants, linked to companies' characteristics, of presence of female directors on boards in an emerging markets context. This is the first research, as soon as we know, to use count data models to study women representation in companies' boardrooms. We also use logistic regression, following 
Hillman et al. (2007), to analyze the factors associated with the probability to have or not female representants in the board of directors.

Overall, the results indicate that several factors contribute to the presence of woman directors in Brazilian companies' boards. Characteristics as firm size, firm control, board size, firm industry and performance are important determinants of female representation on the boards studied.

Corporate boards of directors are the focus of many attempts to improve corporate governance (Boone et al., 2007). Our findings contribute to the literature that examines determinants of gender diversity on firms' boards and policies to enhance women participation in corporate high-level positions and can show possible impacts of regulation in the emerging market context and finally help policymakers to choose and design strategies to increase gender diversity on boards.

As future studies, it would be relevant to analyze other developing countries, to consider not only listed companies and companies that decided to adopt good practices of corporate governance of the segments of the stock exchange and investigate other possible drivers of the women representation on boards based in other theories and fields of research.

\section{Disclaimer}

The opinions expressed in this work are those of the author and not necessarily those of the Banco Central do Brasil (Central Bank of Brazil).

\section{Acknowledgement}

The author acknowledges the financial support received from Coordenação de Aperfeiçoamento de Pessoas de Nível Superior - CAPES/Brazil for this research. I also thank the participants of "Gender, Work and Organization: A South American Workshop" in São Paulo for helpful suggestions and comments.

\section{References}

Abreu, R. S. F. (2019). Legal perspective on gender diversity in the board rooms of BRICS, focusing on the Brazilian example. Unpublished Dissertation, LLM in International Financial Law. King's College London. Retrieved from https://www.researchgate.net/publication/337427879

Adams, R. B., \& Ferreira, D. (2009). Woman in the boardroom and their impact on governance and performance. Journal of Financial Economics, 94(2), 291-309. https://doi.org/10.1016/j.jfineco.2008.10.007

Adams, R. B., \& Kirchmaier, T. (2016). Women on boards in finance and STEM industries. American Economic Review: Papers \& Proceedings 2016, 106(5), 277-281. https://doi.org/10.1257/aer.p20161034

Ahmed, A., Higgs, H., Ng, C., \& Delaney, D. A. (2018). Determinants of women representation on corporate boards: evidence from Australia. Accounting Research Journal, 31(3), 326-342. https://doi.org/10.1108/ARJ-11-2015-0133

Ali, M. (2018). Determinants and consequences of board size: conditional indirect effects. Corporate Governance: The International Journal of Business in Society, 18(1), 165-184. https://doi.org/10.1108/CG-01-2016-0011

Bøhren, Ø., \& Staubo, S. (2014). Does mandatory gender balance work? Changing organizational form to avoid board upheaval. Journal of Corporate Finance, 28, 152-168. https://doi.org/10.1016/j.jcorpfin.2013.12.005

Boone, A. L., Field, L. C., Karpoff, J. M., \& Raheja, C. G. (2007). The determinants of corporate board size and composition: an empirical analysis. Journal of Financial Economics, 85(1), 66-101. https://doi.org/10.1016/j.jfineco.2006.05.004

Cameron, A. C., \& Trivedi, P. K. (2009). Microeconometrics using stata. Stata Press. https://doi.org/10.1111/1475-4932.12006

Chen, C. H., \& Al-Najjar, B. (2012). The determinants of board size and independence: evidence from China. International Business Review, 21(5), 831-846. https://doi.org/10.1016/j.ibusrev.2011.09.008

Chen, J., Leung, W. S., \& Goergen, M. (2017). The impact of board gender composition on dividend payouts. Journal of Corporate Finance, 43, 86-105. https://doi.org/10.1016/j.jcorpfin.2017.01.001

Chong, L.-L., Ong, H. B., \& Tan, S.-H. (2018). Corporate risk-taking and performance in Malaysia: the effect of board composition, political connections and sustainability practices. Corporate Governance: The International Journal of Business in Society, 18(4), 635-654. https://doi.org/10.1108/CG-05-2017-0095 
Coles, J. L., Daniel, N. D., \& Naveen, L. (2008). Boards: does one size fit all?. Journal of Financial Economics, 87(2), 329-356. https://doi.org/10.1016/j.jfineco.2006.08.008

Fama, E., \& Jensen, M. (1983). Separation of ownership and control. Journal of Law and Economics, 26, 301-326. https://doi.org/10.1086/467037

Guest, P. M. (2008). The determinants of board size and composition: evidence from the UK. Journal of Corporate Finance, 14(1), 51-72. http://doi.org/10.1016/j.jcorpfin.2008.01.002

Hillman, A. J., Shropshire, C., \& Cannella, A. (2007). Organizational predictors of women on corporate boards. Academy of Management Journal, 50(4), 941-952. https://doi.org/10.5465/amj.2007.26279222

Jensen, M. C., \& Meckling, W. H. (1976). Theory of the firm: managerial behavior, agency costs and ownership structure. Journal of Financial Economics, 3(4), 305-350. https://doi.org/10.1016/0304-405X(76)90026-X

Kirsch, A. (2018). The gender composition of corporate boards: a review and research agenda. The Leadership Quarterly, 29(2), 346-364. https://doi.org/10.1016/j.leaqua.2017.06.001

Lara, J. M. G., Osma, B. G., Mora, A., \& Scapin, M. (2017). The monitoring role of female directors over accounting quality. Journal of Corporate Finance, 45, 651-668. https://doi.org/10.1016/j.jcorpfin.2017.05.016

Linck, J. S., Netter, J. M., \& Yang, T. (2008). The determinants of board structure. Journal of Financial Economics, 87(2), 308-328. https://doi.org/10.1016/j.jfineco.2007.03.004

Mateos de Cabo, R., Gimeno, R., \& Escot, L. (2011). Disentangling discrimination in Spanish boards of directors. Corporate Governance: An International Review, 19(1), 77-95. https://doi.org/10.1111/j.1467-8683.2010.00837.x

Mateos de Cabo, R., Gimeno, R., \& Nieto, M. J. (2012). Gender diversity on European banks' boards of directors. Journal of Business Ethics, 109(2), 145-162. https://doi.org/10.1007/s10551-011-1112-6

Sojo, V. E., Wood, R. E., Wood, S. A., \& Wheeler, M. A. (2016). Reporting requirements, targets, and quotas for women in leadership. The Leadership Quarterly, 27(3), 519-536. https://doi.org/10.1016/j.leaqua.2015.12.003

Spencer Stuart. (2018). 2018 Brazil Spencer Stuart Board Index. Retrieved from https://www.spencerstuart.com/-/media/2019/january/brasil_board_index_2018.pdf

Terjesen, S., Aguilera, R. V., \& Lorenz, R. (2015). Legislating a woman's seat on the board: institutional factors driving gender quotas for boards of directors. Journal of Business Ethics, 128(2), 233-251. https://doi.org/10.1007/s10551-014-2083-1

Ye, D., Deng, J., Liu, Y., Szewczyk, S. H., \& Chen, X. (2019). Does board gender diversity increase dividend payouts? Analysis of global evidence. Journal of Corporate Finance, 58, 1-26. https://doi.org/10.1016/j.jcorpfin.2019.04.002

Young, M. N., Peng, M. W., Ahlstrom, D., Bruton, G., \& Jiang, Y. (2008). Corporate governance in emerging economies: a review of the principal-principal perspective. Journal of Management Studies, 45(1), 198-220. https://doi.org/10.1111/j.1467-6486.2007.00752.x

\section{Copyrights}

Copyright for this article is retained by the author(s), with first publication rights granted to the journal.

This is an open-access article distributed under the terms and conditions of the Creative Commons Attribution license (http://creativecommons.org/licenses/by/4.0/). 